\title{
Desain Pembelajaran Student's Conceptual Construction Guider Berdasarkan Kesulitan Mahasiswa Calon Guru Fisika pada Konsep Gerak Parabola
}

\author{
Duden Saepuzaman ${ }^{\text {a) }}$, Saeful Karim ${ }^{\text {b) }}$ \\ Departemen Pendidikan Fisika, FPMIPA, Universitas Pendidikan Indonesia, \\ Jl. Dr. Setiabudhi No. 229 Bandung 40154

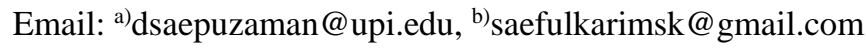

\begin{abstract}
This research is motivated finding of the student difficulties in projectile motion. In general, the difficulties students in understanding the concept of projectile motion as follows. First, draw the vector component's in the direction $x$ (horizontal) and $y$ (vertical). Second, distinguish the velocity vector's, the vector component of velocity, the velocity vector component in the $\mathrm{x}$ and $\mathrm{y}$ directions. Third, too focus on formula's for half a projectile trajectory, maximum height, maximum distance. Fourth, always assumed final velocity moving object projectile when it hits the ground is always zero. Fifth, the velocity to zero at the top (only the speed in the vertical direction is zero). Sixth, the acceleration is owned by the object in the $x$ and $y$ directions. Seventh, found some students use the law of sines cosines rule's on the determination of the distance/ height (although the determination of the distance/ high based on the speed information). In Prediction, the process of learning that takes less facilitate the development of thinking ability of students to build its own concept (constructivism). This research aims to create a lesson plan called Student's Conceptual Construction Guider. The method used is descriptive analysis method. Conceptual understanding of students are evaluated through tests shaped conceptual description. The results showed that the learning Student's Conceptual Construction Guider can facilitate the development of thinking ability of students to build its own concept in understanding the concept of a projectile motion.
\end{abstract}

Keywords: Student's Conceptual Construction Guides, student difficulties, Projectile Motion

\begin{abstract}
Abstrak
Penelitian ini dilatarbelakangi karena ditemukannya kesulitan-kesulitan mahasiswa dalam mempelajari konsep gerak parabola. Secara umum, kesulitan-kesulitan mahasiswa dalam memahami konsep gerak parabola sebagai berikut. Pertama, menggambarkan vektor komponen dalam arah $x$ (horizontal) dan $y$ (vertikal). Kedua, membedakan vektor kecepatan, vektor komponen kecepatan, komponen vektor kecepatan dalam arah $x$ dan $y$. Ketiga, terfokus pada hapalan rumus waktu yang ditempuh peluru untuk lintasan setengah parabola, tinggi maksimum, jarak terjauh maksimum. Keempat, selalu beranggapan kecepatan akhir benda yang bergerak parabola ketika menyentuh tanah selalu nol. Kelima, kecepatan benda nol di puncak (padahal hanya kecepatan dalam arah vertikal yang nol). Keenam, percepatan dimiliki oleh benda dalam arah x maupun y. Ketujuh, ditemukan beberapa mahasiswa menggunakan aturan sinus cosinus segitiga pada penentuan jarak/ ketinggian dan sebaliknya (padahal penentuan jarak/ ketinggian berdasarkan informasi kecepatan). Diduga kuat, proses
\end{abstract}


pembelajaran yang terjadi kurang memfasilitasi pengembangan kemampuan berpikir mahasiswa untuk membangun konsepnya sendiri (konstruktivisme). Penelitian ini bertujuan untuk membuat sebuah rancangan pembelajaran yang disebut Student's Conceptual Construction Guider. Metode yang digunakan adalah metode analisis deskriftif. Pemahaman konseptual mahasiswa dievaluasi melalui tes konseptual yang berbentuk uraian. Hasil penelitian menunjukkan bahwa pembelajaran Student's Conceptual Construction Guider dapat memfasilitasi memfasilitasi pengembangan kemampuan berpikir mahasiswa untuk membangun konsepnya sendiri dalam memahami konsep gerak parabola.

Kata-kata kunci: Student's Conceptual Construction Guider, kesulitan mahasiswa, Gerak Parabola

\section{PENDAHULUAN}

Semua komponen di dalam sistem pembelajaran mengharapkan tujuan pembelajaran dapat tercapai secara efektif. Termasuk dosen senantiasa mengharapkan mahasiswa mencapai hasil belajar sesuai dengan yang telah ditetapkan dalam kompetensi perkuliahan. Data di lapangan menunjukkan masih ditemukannya pencapaian hasil belajar yang kurang optimal pada perkuliahan Fisika Dasar 1. Data skor yang diperoleh mahasiswa di perkuliahan Fisika Dasar 1, sebagai contoh Tes Unit 1 ratarata nilai mahasiswa 53 (skala maksimal 100) pada tahun akademik 2013/2014 dan 49 pada tahun akademik 2014/2015. Materi Tes Unit 1 Fisika Dasar 1 meliputi sistem pengukuran, vektor dan skalar, gerak satu dimensi dan gerak dua dimensi. Analisis lebih lanjut pada lembar jawaban mahasiswa ditemukan dominasi terbesar kesalahan mahasiswa adalah pada materi gerak dua dimensi yaitu gerak parabola. Hampir $67 \%$ mahasiswa masih mengalami kesulitan dalam memahami konsep gerak parabola. Secara lebih spesifik, beberapa kesulitan mahasiswa pada gerak parabola sebagai berikut. Pertama, menggambarkan vektor komponen dalam arah $x$ (horizontal) dan $y$ (vertikal). Kedua, membedakan vektor kecepatan, vektor komponen kecepatan, komponen vektor kecepatan dalam arah $x$ dan $y$. Ketiga, terfokus pada hapalan rumus waktu yang ditempuh peluru untuk lintasan setengah parabola, tinggi maksimum,jarak terjauh maksimum, dan sulit menerapkan pada situasi baru yang berbeda kondisinya, misalnya posisi vertikal dan horizontal untuk setiap waktu, posisi awal dan sudut yang berbeda dengan contoh. Keempat, selalu beranggapan kecepatan akhir benda yang bergerak parabola ketika menyentuh tanah selalu nol. Kelima, kecepatan benda nol di puncak (padahal hanya kecepatan dalam arah vertikal yang nol). Keenam, percepatan dimiliki oleh benda dalam arah $x$ maupun $y$ (padahal percepatan hanya dimiliki dalam arah vertikal $y$ ). Ketujuh, ditemukan beberapa mahasiswa menggunakan aturan sinus cosinus segitiga pada penentuan jarak/ ketinggian dan sebaliknya (padahal penentuan jarak/ketinggian berdasarkan informasi kecepatan).

Berdasarkan temuan ini, banyak faktor yang mempengaruhi tidak optimalnya hasil belajar yang dicapai mahasiswa. Tetapi diduga kuat proses pembelajaran yang terjadi kurang memfasilitasi pengembangan kemampuan berpikir mahasiswa untuk membangun konsepnya sendiri (konstruktivisme). Sebuah proses pembelajaran merupakan salah satu aspek penting bagi peningkatan prestasi konseptual siswa (karim, S 2015 dan Sriyansah S, 2015). Menurut studi pendahuluan dan refleksi dari proses pembelajaran sebelumnya, pembelajaran sebelumnya kurang memfasilitasi siswa dalam membangun pengetahuan mereka. Ketidakoptimalan proses pembelajaran nampak dari perangkat pembelajaran yang direncanakan, proses pembelajaran yang berlangsung di kelas, aktivitas mahasiswa dan aktivitas dosen. Hasil pengamatan pembelajaran dalam kelas menunjukkan bahwa proses pembelajaran secara keseluruhan dimulai dari pemberian informasi secara langsung melalui ceramah, power point, dan diakhiri dengan contoh soal dan latihan untuk dikerjakan di rumah. Proses pembelajaran ini kurang memfasilitasi siswa untuk langsung membangun pengetahuan sendiri (Mc Demott, 2001). Mahasiswa cenderung hanya menerima konsep-konsep fisika yang diberikan tanpa komentar apapun, meskipun sesekali diberi kesempatan untuk bertanya. Sesekali mahasiswa bertanya dan cenderung mahasiswa tertentu. Pembelajaran informatif seperti ini diduga kuat penyebab kurang optimalnya hasil belajar. Oleh karena itu, perlu ada upaya redesain pembelajaran yang secara khusus dirancang dan dapat membantu memfasilitasi mahasiswa untuk mengkonstruksi pengetahuannya sendiri (Piaget, 1964). Pengembangan proses pembelajaran merupakan penting bagi dalam pengembangan kurikulum. Heuvelen telah berhasil 
mengintegrasikan pembelajaran berbasis problem solving menggunakan multiple representatif dalam perkuliahan Fisika Dasar (Heuvalen 1991). Aiello-Nicosia dan Sperandeo-Mineo merekonstruksi konten Fisika untuk calon guru ( Aillo, dkk 2000). Selain itu, Duit telah merekonstruksi kerangka sistem pendidikan meliputi desain dan evaluasi dalam pembelajaran lingkungan (Duit, 2012).

Penelitian ini akan memfokuskan pada produk redesain pembelajaran yang menggunakan Lembar Kerja Mahasiswa (LKM) untuk memandu pengkonstruksian pengetahuan Mahasiswa. LKM ini selanjutnya disebut Student's Conceptual Construction Guider. Redesain ini dibatasi pada konsep gerak parabola dan pencapaian hasil belajar mahasiswa pada konsep gerak parabola.

\section{METODE}

Penelitian deskriptif ini digunakan untuk menganalisis redesain pembelajaran terhadap penguasaan konsep mahasiswa pada konsep gerak parabola. Subjek penelitian yang digunakan dalam pembelajaran konvensional dan pembelajaran Student's Conceptual Construction Guider masingmasing 41 dan 39 calon guru Fisika yang mengontrak perkuliahan Fisika Dasar 1 (PHY 100) pada tahun akademik 2015/2016 di Universitas Pendidikan Indonesia, Bandung. Penguasaan konseptual akan diuji dengan menggunakan tes konseptual gerak parabola yang mewakili tiap bagian konsep essensial.

\section{HASIL DAN PEMBAHASAN}

Bagian ini akan membahas tentang rekonstruksi belajar dan prestasi penguasaan konseptual siswa pada konsep gerak parabola.

\section{Rekonstruksi pembelajaran}

Redesain pembelajaran dirancang berdasarkan analisis kesulitan siswa dalam belajar konsep gerak parabola yang diperoleh berdasarkan analisis pada jawaban mahasiswa selama dua tahun akademik pada tahun akademik 2013/2014 dan 2014/2015. Kegiatan redesain yang dilakukan termasuk menentukan tujuan yang diharapkan pembelajaran, urutan pembelajaran, dan evaluasi. Pertemuan dilakukan 1 kali pertemuan selama 100 menit ( $2 \mathrm{sks}$ ).

Sebagai gambaran umum desain pembelajaran awal disajikan dalam tabel di bawah ini. Di dalam pelaksanaanya, pembelajaran dimulai dengan informasi materi yang akan dipelajari. Kegiatan inti berupa penyampaian materi melalui power point yang berisikan uraian konsep yang dipelajari. Setelah penyampaian materi selesai, dilanjutkan dengan contoh soal. Di akhir pembelajaran, dosen menyampaikan tugas/latihan soal-soal untuk dikerjakan di rumah.

Proses pembelajaran ini dipandang kurang memfasilitasi mahasiswa untuk mengkonstruksi pengetahuannya. Mahasiswa cenderung pasif dan hanya menerima informasi yang disampaikan dosen. Ditinjau dari latihan/tugas yang dikerjakan mahasiswa terlalu menekankan pada aspek kuantitatif (hitungan) dalam pemecahan masalah daripada pertanyaan kualitatif yang konseptual. Secara umum rencana pembelajaran yang biasa diterapkan (sebelum redesain) disjaikan dalam TABEL 1.

Kondisi ini diduga akan menyulitkan juga untuk mendiagnosis kesulitan-kesulitan konseptual yang dialami siswa dalam memahami konsep-konsep fisika (Mc Dermott, 2001).

TABEL 1. Rencana Pembelajaran Awal

\begin{tabular}{|c|c|c|c|c|c|c|}
\hline $\begin{array}{c}\text { Kompetensi } \\
\text { Dasar }\end{array}$ & Indikator & $\begin{array}{l}\text { Materi } \\
\text { Pokok }\end{array}$ & $\begin{array}{c}\text { Pengalaman } \\
\text { Belajar }\end{array}$ & Media & $\begin{array}{l}\text { Eva- } \\
\text { luasi }\end{array}$ & Sumber \\
\hline $\begin{array}{l}\text { Menguasai } \\
\text { pengetahuan } \\
\text { dasar gerak } \\
\text { dalam dua } \\
\text { dimensi secara } \\
\text { komprehensip, } \\
\text { mantap, dan }\end{array}$ & $\begin{array}{l}\text { - Menggunakan sistem } \\
\text { koordinat sebagai } \\
\text { kerangka acuan untuk } \\
\text { meninjau gerak dalam } \\
\text { dua dimensi. } \\
\text { - Menjabarkan dan } \\
\text { menerapkan }\end{array}$ & $\begin{array}{l}\text { - Kerangka } \\
\text { acuan dan } \\
\text { sistem } \\
\text { koordinat } \\
\text { - Posisi, } \\
\text { perpindahan } \\
\text { - Kecepatan }\end{array}$ & $\begin{array}{l}\text { Menerima } \\
\text { informasi dan } \\
\text { berdiskusi } \\
\text { tentang } \\
\text { kerangka } \\
\text { acuan, sistem } \\
\text { koordinat, }\end{array}$ & $\begin{array}{l}\text { - Komp } \\
\text { - OHP }\end{array}$ & $\begin{array}{l}\text { - PR- } \\
3 \\
-\mathrm{UT} \\
\mathrm{S}\end{array}$ & $\begin{array}{l}\text { - H1:75 } \\
-92 \\
\text { - Tipler } \\
\text { - Giancol } \\
\text { li }\end{array}$ \\
\hline
\end{tabular}




\begin{tabular}{|c|c|c|c|}
\hline $\begin{array}{l}\text { mendalam serta } \\
\text { dapat } \\
\text { mengembangkan } \\
\text { dan } \\
\text { mengaplikasikan } \\
\text { nya untuk } \\
\text { mempelajari } \\
\text { pengetahuan } \\
\text { fisika yang lebih } \\
\text { tinggi sesuai } \\
\text { dengan } \\
\text { perkembangan } \\
\text { sains dan } \\
\text { teknologi }\end{array}$ & $\begin{array}{l}\text { persamaan-persamaan } \\
\text { posisi, perpindahan, } \\
\text { kecepatan dan } \\
\text { percepatan dalam dua } \\
\text { dimensi. } \\
\text { - Membedakan } \\
\text { percepatan radial dan } \\
\text { percepatan tangensial. } \\
\text { - Menjabarkan dan } \\
\text { menerapkan } \\
\text { persamaan-persamaan } \\
\text { gmb, gmbb dan gerak } \\
\text { peluru. } \\
\text { - Membuat dan } \\
\text { menginterpretasikan } \\
\text { grafik posisi, } \\
\text { kecepatan dan } \\
\text { percepatan fungsi } \\
\text { waktu untuk gmb, } \\
\text { gmbb dan gerak } \\
\text { peluru. } \\
\text { - Menyelesaikan soal- } \\
\text { soal gerak dalam dua } \\
\text { dimensi. }\end{array}$ & $\begin{array}{l}\text { - Percepatan } \\
\text { - GMB dan } \\
\text { GMBB } \\
\text { - Gerak peluru }\end{array}$ & $\begin{array}{l}\text { posisi, } \\
\text { kecepatan dan } \\
\text { percepatan } \\
\text { dalam dua } \\
\text { dimensi. } \\
\text { Menerima } \\
\text { informasi, } \\
\text { tanya jawab } \\
\text { dan berdiskusi } \\
\text { mengenai } \\
\text { grafik dan } \\
\text { persamaan } \\
\text { gmb, gmbb, } \\
\text { dan gerak } \\
\text { peluru. } \\
\text { Mengerjakan } \\
\text { contoh soal } \\
\text { gmb, gmbb, } \\
\text { dan gerak } \\
\text { peluru } \\
\text { Berlatih soal- } \\
\text { soal gmb, } \\
\text { gmbb, dan } \\
\text { gerak peluru. }\end{array}$ \\
\hline
\end{tabular}

Dengan dasar pemikiran dan kodisi di atas, dipandang sangat penting untuk dipertimbangkan sebuah redesain pembelajaran yang dapat memfasilitasi mahasiswa untuk mengkonsruk pengetahuannya sendiri. Redesain pembelajaran yang dikembangkan secara umum meliputi lima tahapan pembelajaran seperti yang dikembangkan pertama kali oleh Driver and Oldham (Driver R dan Oldham, 1986). Umumnya, tahapannya meliputi orientasi (orientation), elisitasi (elicitation), restrukturisasi (restructure), aplikasi (application) dan ulasan (review). Sebagai contoh di awal pembelajaran untuk mencapai tujuan pembelajaran "menjelaskan proses terjadinya lintasan gerak parabola dari gerak peluru." Pembelajarannya dimulai dengan review terkait besaran-besaran fisika terkait gerak dua dimensi. Kemudian diarahkan untuk menganalisis demonstrasi terkait gerak parabola dengan melemparkan sebuah benda dengan elevasi tertentu. Hal ini diharapkan mahasiswa dapat memahami konsep gerak parabola baik secara fenomena fisis maupun secara kajian teoritis.

Pada langkah pertama ini orientasi, redesain pembelajaran dimulai dengan mahasiswa duduk berkelompok, dengan formasi kursi lingkaran (usahakan distribusi mahasiswa berdasarkan kemampuan akademik dan gendernya merata; setiap kelompok terdiri dari 3-4 orang). Hal ini dilakukan agar didalam pembelajaran terjadi diskusi sehingga diperoleh capaian hasil belajar yang baik. Pembelajaran awal dimulai dengan review materi-materi sebelumnya yang pemahamannya diperlukan untuk pembelajaran. Dalam pembelajaran gerak parabola, review meliputi pemahaman mahasiswa terkait besaran-besaran fisika yang terlibat dalam kinematika gerak dua dimensi. Review yang dilakukan berupa pertanyaan-pertanyaan. Pertanyaan-pertanyaan ini berguna untuk menyegarkan kembali ingatan dan pemahaman mahasiswa tentang konsep-konsep sebelumnya, yang akan digunakan dan dikembangkan pada pembahasan gerak parabola. Pertanyaan-pertanyaan yang digunakan dalam review gerak parabola diantaranya:

1. Apa yang dimaksud dengan perpindahan, kecepatan, dan percepatan?

2. Apa bedanya kecepatan dan kelajuan?

3. Bagaimana cara menentukan kecepatan sesaat dari grafik posisi terhadap waktu?

4. Tuliskan kembali persamaan-persamaan penting yang menghubungkan perpindahan, kecepatan, percepatan, dan waktu yang berlaku untuk gerak benda dengan percepatan konstan!

Pada awal kegiatan inti pembelajaran dilanjutkan dengan demonstrasi

- Demonstrasi-1 : Melemparkan sebuah kelereng vertikal ke atas dengan kecepatan awal tertentu dan mengamati pergerakkannya 
- Demonstrasi-2 : Melemparkan 2 buah kelereng secara bersamaan dengan menggunakan alat (free fall experiment). Kelereng yang pertama akan jatuh bebas, dan kelereng yang kedua akan menempuh lintasan setengah parabola

- Demonstrasi-3 : Melemparkan sebuah kelereng dengan kecepatan awal tertentu dan membentuk sudut elevasi tertentu dan mengamati lintasan geraknya.

Demonstrasi ini dilakukan berdasarkan pertimbangan beberapa tujuan. Pertama, mahasiswa menemukan adanya perbedaan dan persamaan gerak parabola dengan gerak vertikal ke atas. Kedua, Analisis teoritis gerak parabola untuk arah vertikal sama dengan gerak parabola untuk komponen verikal. Ketiga, kriteria awal yang memenuhi agar sebuah benda bergerak parabola.

Selama dan setelah demonstrasi, mahasiswa diarahkan untuk mengembangkan kecerdasan berfikirnya dengan pertanyaan-pertanyaan arahan yang ada dalam Lembar Kerja Mahasiswa (LKM) yang berfokus Student's Conceptual Construction Guider. Pertanyaan-pertanyaan dalam LKM ini dikembangkan dengan mempertimbangkan beberapa temuan, masukan dan rujukan sebagai berikut.

1) Analisis jawaban mahasiswa pada saat ujian yang menunjukkan adanya beberapa letak kesalahan dan kurang tepatnya pengetahuan mahasiswa dalam gerak parabola .

2) Beberapa masukan dari tim dosen mata kuliah Fisika Dasar 1 yang berfokus pada pertimbangan; operasionalisasi dalam kelas, karakteristik mahasiswa, kompetensi mata kuliah, learning outcome Prodi, dan kedudukan mata kuliah Fisika Dasar 1 terhadap mata kuliah lainnya.

3) Beberapa pertanyaan dalam LKM mengadopsi beberapa pertanyaan arahan yang telah di kembangkan Randall melalui pnelitian yang terus berkelanjutan.

Selama tahapan Elicitation and Restructure, mahasiswa dibimbing untuk menjawab pertanyaanpertanyaan penyelidikan dalam memecahkan permasalahan fisika yang utama. Diharapkan mahasiswa terlibat langsung dalam proses pembelajaran untuk membangun konsep. Berdasarkan pengamatan selama tahapan ini dalam pemebelajaran, terungkap beberapa pemahaman awal mahasiswa. Hal ini nampak adanya diskusi terutama untuk hal-hal dan konsep yang didalam kelompoknya terjadi perbedaan konsepsi. Setiap mahasiswa mengungkapkan gagasan disertai dengan landasan teoritis fisika yang dipandang kuat untuk mendukung argumennya sampai diperoleh suatu konsepsi bersama yang tepat untuk menjawab permasalahan dalam LKM Student's Conceptual Construction Guider. Di tahapan inilah mahasiswa mencoba kembali merestruktur atau merekonstruksi pengetahuannya.

Tahapan Aplikasi merupakan tahapan dimana mahasiswa menerapkan pengetahuannya dalam menyelsaikan persoalan terkait gerak parabola. Masih dalam kelompok, mahasiswa berdiskusi tentang konsep gerak parabola secara komprehensif Siswa berargumen, berdiskusi, mempertimbangkan dan memutuskan beberapa solusi dalam pemecahan masalah fisika utama.

Pada langkah keempat ulasan/review, mahasiswa diminta untuk meninjau semua pelajaran. Kemudian mereka memecahkan latihan-latihan terpilih yang mewakili setiap sub topik pada Tipler (Tipler 1991). Kegiatan ini diharapkan dapat memperkuat pemahaman konseptual siswa. Secara umum, redesain pembelajaran yang dilakukan disjaikan dalam TABEL 2.

\section{Pemahaman Konseptual Mahasiswa}

Pemahaman konseptual mahasiswa pada gerak parabola dianalisis berdasarkan sub topik. Pertama (C1), komponen vektor dan vektor komponen dalam gerak parabola. Kedua (C2), kecepatan dan posisi benda sebagai fungsi waktu. Ketiga (C3), Jarak dan ketinggian maksimum. Secara umum persentase pemahaman konseptual mahasiswa untuk kelas konvensional dan Student's Conceptual Construction Guider disajikan dalam GAMBAR 1. 
TABEL 2. Redesain Pembelajaran

\begin{tabular}{|c|c|c|}
\hline Desain sebelumnya & Kelemahan & Redesain Pembelajaran \\
\hline $\begin{array}{l}\text { Kegiatan Pendahuluan } \\
\text { Pemaparan materi pelajaran dan } \\
\text { materi sub-topik yang akan } \\
\text { dipelajari }\end{array}$ & $\begin{array}{l}\text { - Pembelajaran tidak } \\
\text { dimulai dengan review/ } \\
\text { ulasan materi } \\
\text { sebelumnya } \\
\text { - Pembelajaran tidak } \\
\text { dimulai dengan } \\
\text { memotivasi mahasiswa } \\
\text { untuk belajar konsep } \\
\text { fisika secara rinci }\end{array}$ & $\begin{array}{l}\text { Orientation } \\
\text { - Review pembelajaran sebelumnya } \\
\text { untuk lebih menyiapkan } \\
\text { mahasiswa untuk belajar dan } \\
\text { untuk mengingat konsep-konsep } \\
\text { yang telah dipelajari mereka } \\
\text { yang berkaitan. } \\
\text { - Pembelajaran dimulai dengan } \\
\text { demonstrasi dan simulasi video } \\
\text { terkait fenomena fisika untuk } \\
\text { memotivasi siswa dan } \\
\text { menekankan bahwa fisika banyak } \\
\text { fenomena dan aplikasinya dalam } \\
\text { kehidupan sehari-hari. }\end{array}$ \\
\hline $\begin{array}{l}\text { Kegiatan Inti } \\
\text { Penjelasan/Pemaparan Konsep }\end{array}$ & 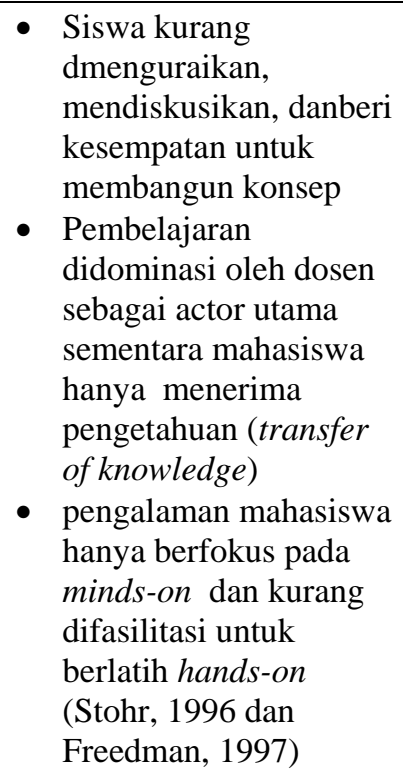 & $\begin{array}{l}\text { Elicitation and Restructure } \\
\text { - Mahasiswa dibimbing untuk } \\
\text { menjawab pertanyaan pertanyaan } \\
\text { penyelidikan dalam memecahkan } \\
\text { permasalah fisika yang utama } \\
\text { - Mahasiswa terlibat langsung } \\
\text { dalam proses pembelajaran untuk } \\
\text { membangun konsep } \\
\text { Application } \\
\text { - Siswa mendiskusikan konsep } \\
\text { gerak parabola secara } \\
\text { komprehensif } \\
\text { - Mahasiswa berargumen, } \\
\text { berdiskusi, mempertimbangkan } \\
\text { danmemutuskan beberapa solusi } \\
\text { dalam pemecahan masalah fisika } \\
\text { utama }\end{array}$ \\
\hline $\begin{array}{l}\text { Kegiatan Penutup } \\
\text { Dosen memberikan tugas } \\
\text { latihan untuk mengevaluasi } \\
\text { pemahaman konseptual } \\
\text { mahasiswa }\end{array}$ & $\begin{array}{l}\text { - Mahasiswa secara aktif } \\
\text { terlibat hanya pada } \\
\text { akhir pembelajaran } \\
\text { dengan menjawab } \\
\text { beberapa latihan. } \\
\text { Padahal idealnya, } \\
\text { mahasiswa harus } \\
\text { terlibat aktif dam } \\
\text { semua tahapan } \\
\text { pembelajaran (Meltzer } \\
\text { D E dan Manivannan, } \\
\text { 2012) }\end{array}$ & $\begin{array}{l}\text { Review } \\
\text { Mahasiswa dipandu untuk dapat } \\
\text { memecahkan beberapa permasalahan } \\
\text { fisika dalam situasi dan konteks yang } \\
\text { baru }\end{array}$ \\
\hline
\end{tabular}

GAMBAR 1 mengilustrasikan adanya perbedaan pencapaian pemahaman konsep mahasiswa antara sebelum menerapakan redesain pembelajaran (konvensional) dengan setelah menerapkan redesain pembelajaran Student's Conceptual Construction Guider. Perbedaan pencapaian pemahaman ini terjadi pada jenjang kognitif $\mathrm{C} 1, \mathrm{C} 2$ dan $\mathrm{C} 3$. Ini menunjukkan penerapan redesain pembelajaran Student's Conceptual Construction Guider bisa meningkatkan pemahaman konsep fisika mahasiswa calon guru fisika pada materi gerak parabola. 


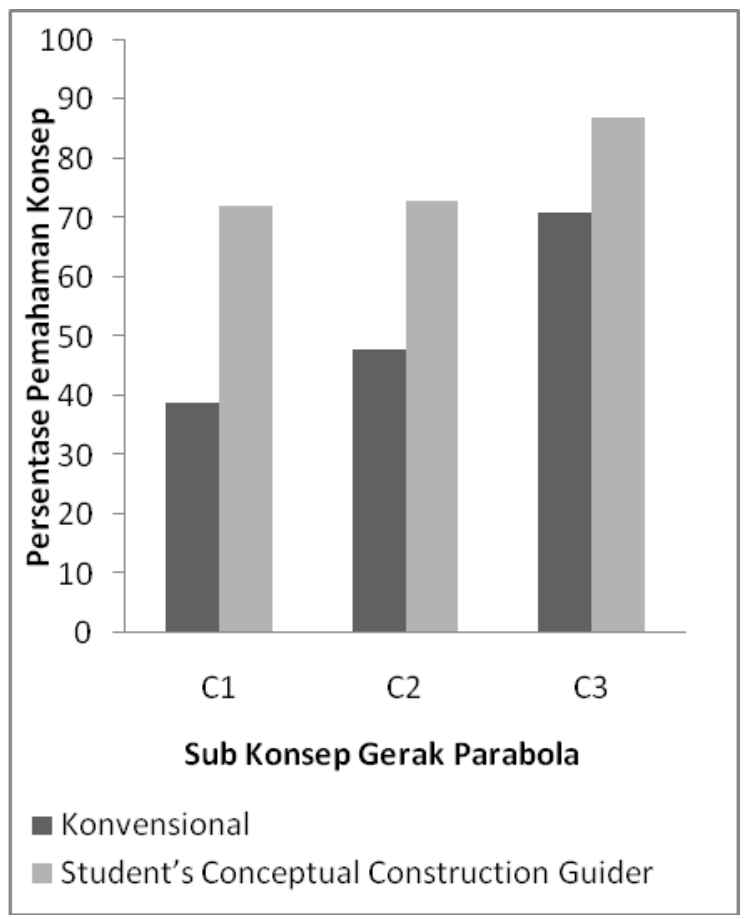

GAMBAR 1. Persentase mahasiswa yang menjawab benar untuk setiap konsep

\section{PENUTUP}

Redesain pembelajaran gerak parabola telah dilaksanakan. Studi ini memfasilitasi mahasiswa calon guru fisika dalam membangun konsep fisika. Selain itu, penelitian ini juga memberikan dampak positif pada pemahaman konseptual mahasiswa. Redesain pembelajaran ini telah dapat diterapkan sebagai alternatif pembelajaran untuk mempelajari konsep gerak parabola.

\section{UCAPAN TERIMA KASIH}

Terimakasih kepada semua pihak yang telah banyak membantu dalam penelitian ini, terutama mahasiswa jurusan pendidikan Fisika angkatan 2015 yang mengontrak mata kuliah Fisika Dasar 1 Universitas Pendidikan Indonesia dan yang telah banyak memberikan kontribusi pada penelitian ini.

\section{REFERENSI}

Aiello-Nicosia M L and Sperandeo-Mineo R M. 2000.Int. J. Sci. Educ.22 1085-1097

Driver R dan Oldham V . 1986. Studies di Ilmu Education13 105-122

Duit R .2012. Science Penelitian Pendidikan dan Praktik di Eropa: (. Eds) retrospektif dan Calon di Doris Jorde dan Justin Dillon (Rasa Penerbit) pp 13-37

Freedman M P . 1997. J. Res. Sci. Teach.34 343-357

Heuvelen A V . 1991. Am. J. Phys.59 891-897

McDermott L C. 2001. Am. J. Phys.69 1127-1137

Meltzer D E dan Manivannan K. 2002. Am. J. Phys.70 639-654

Piaget J . 1964. J. Res. Sci. Teach.2, 176-186 
Saeful K, Saepuzaman D dan SriyansyahSP . 2015. Jurnal Penelitian dan Pengembangan Pendidikan Fisika1 (1) 85-90

Sriyansyah S P, Suhandi A, Saepuzaman D . 2015. Indonesia Jurnal Ilmu Education4 75-82

Stohr-berburu P M . 1996. J. Res. Sci. Teach.33 101-109

Tipler P A . 1991. Physics untuk Ilmuwan dan Engineers3rd ed (Layak Publisher, NY) 